\title{
Immunogenicity Study
}

National Cancer Institute

\section{Source}

National Cancer Institute. Immunogenicity Study. NCI Thesaurus. Code C120842.

A study that assesses an agent's ability to provoke an immune response (humoral and/or cell-mediated) in the subject. 